\title{
Culture and PCR based detection of bacteria causing urinary tract infection in urine specimen
}

\author{
Ghulam Sarwar Pirkani ${ }^{1}$, Mohammad Arif Awan², \\ Ferhat Abbas ${ }^{3}$, Mohammad Din ${ }^{4}$
}

\begin{abstract}
Objectives: Urinary tract infections are the second most common bacterial infections occurring at all ages and both sexes. The increasing rate of antibiotic resistance is a global concern. The use of routinely used antibiotics is resulting in treatment failure. The objective of this study was to diagnose the urinary tract infections by routine culture sensitivity test and by molecular methods.

Methods: This study was conducted in Microbiology laboratory, Bolan Medical Complex Hospital, Quetta, from July $1^{\text {st }}$ to $31^{\text {st }}$ March 2019. Isolates were identified biochemically by API20E \& API20NE. Antibiogram was performed using disc diffusion Kirby Bauer technique. The 16S rDNA gene approach was used for molecular identification of bacterial isolates. The presence of the $b l a_{\mathrm{NDM}-1}$ gene was identified by polymerase chain reaction (PCR).

Results: We isolated 146 bacterial isolates namely Escherichia coli $(n=99) 67.80 \%$, Klebsiella pneumoniae $(n=33) 22.60 \%$, Pseudomonas aeruginosa $(n=11) 7.53 \%$ and Proteus mirabilis $(n=3) 2.05 \%$ from 2032 urine samples. The resistance pattern was dominated by Multi Drug Resistance (MDR). Remarkably, four isolates of Escherichia coli $(n=3)$ and Klebsiella pneumoniae $(n=1)$ were displaying resistance against a range of antibiotics used in the study, including carbapenems but sensitive to tigecycline and polymyxins only, suggesting extensive drug resistance having blaNDM-1 gene.

Conclusion: This is the first report on direct molecular detection of bacterial pathogens from urinary tract infected patients in Balochistan. The presence of $b / a_{\mathrm{NDM}-1}$ in different bacterial species and their extensive drug resistance pattern poses a significant clinical threat. Molecular detection of bacteria and resistant gene may reduce the diagnostic time of patients.
\end{abstract}

KEYWORDS: Antimicrobial susceptibility, blaNDM1, Disc diffusion, Multi drug resistance, Urinary Tract Infection (UTI).

doi: https://doi.org/10.12669/pjms.36.3.1577

How to cite this:

Pirkani GS, Awan MA, Abbas F, Din M. Culture and PCR based detection of bacteria causing urinary tract infection in urine specimen. Pak J Med Sci. 2020;36(3):391-395. doi: https://doi.org/10.12669/pjms.36.3.1577

This is an Open Access article distributed under the terms of the Creative Commons Attribution License (http://creativecommons.org/licenses/by/3.0), which permits unrestricted use, distribution, and reproduction in any medium, provided the original work is properly cited.

1. Ghulam Sarwar Pirkani, M.Phil.

2. Mohammad Arif Awan, PhD.

3. Ferhat Abbas, PhD.

4. Mohammad Din, M.Phil.

1,4: Pathology Department,

Bolan University of Medical and Health Sciences, Quetta, Pakistan.

2, 3: Center for Advanced Studies in Vaccinology and Biotechnology, University of Balochistan, Quetta, Pakistan.

Correspondence:

Dr. Ghulam Sarwar Pirkani,

Professor of Microbiology, Bolan University of Medical and Health Sciences, Consultant Microbiologist,

Bolan Medical Complex Hospital, Quetta, Pakistan Email: pirkani77@gmail.com

* Received for Publication:

August 29, 2019

* Revision Received:

* Revision Accepted: December 25, 2019

\section{INTRODUCTION}

Urinary tract infection (UTI) results from the presence and multiplication of microorganisms, in one or more structures of the urinary tract. Ninetyfive percent UTI cases are due to bacteria. ${ }^{1}$ Globally, about 150 million people are prone to urinary tract infections every year. ${ }^{2}$ With bacterial infections, urinary tract infection is the second most common type. ${ }^{3}$ The most common bacteria causing UTI, are Escherichia coli, Klebsiella pneumoniae. Pseudomonas aeruginosa, Proteus spp, Staphylococcus saprophyticus and Enterococcus spp. ${ }^{4} \mathrm{UTI}$ is commonly diagnosed by urine analysis. ${ }^{5}$ The presence of pus cells in the 
urine recommends the culture and sensitivity test, which takes 48-72 hour awaiting the final report. Urine examination and confirmed by isolation of uropathogen in urine culture while bacteria present $>1,000 \mathrm{cfu} / \mathrm{ml}$ of urine is a standard threshold. The above mentioned diagnostic procedures are timeconsuming, and take at least three days. A rapid, definitive urine test capable of detecting bacteria would be beneficial in ensuring timely treatment, and in eliminating empirical treatment. Recently, many PCR-based gene tests have been developed for bacterial identification in other body infections. $16 \mathrm{~S}$ rRNA gene is a well-characterized bacterialspecific bio signature used to detect and identify bacteria. ${ }^{6}$ While it is feasible to extract $16 \mathrm{~S}$ rDNA from various infected bodily fluids, including urine as it can be obtained in a non-invasive manner. ${ }^{7}$

The present study, entail the analysis of urine of outdoor and admitted patient's. The urine samples having leukocytes were subjected to routine culture sensitivity and PCR test. The detected bacteria by culture method and molecular method were analyzed. From resistant strains of isolated bacteria resistant gene have also been detected. The time taken by molecular method of detection of resistant gene is generally 3 to 4 hours. ${ }^{8}$ The goal of the study was to give the patients timely molecular based diagnosis and early relief to the affected individuals by using antibiotic of choice specially in case of resistant strains.

\section{METHODS}

Two thousand and thirty two $(n=2032)$ urine samples were collected aseptically in commercially available sterilized wide mouth containers from in and outdoor patients of tertiary care hospitals in Quetta. Demographic data was obtained with the consent of the patients. Samples were immediately sent after collection to the Microbiology laboratory of Bolan Medical Complex hospital, Quetta from July 1st to 31st March 2019. The study was approved by the Institutions Ethical Committee of BMC Hospital (No. E.C.4- 8/2017 dated May 24, 2017).

Urine detail report: All the samples were screened biochemically by commercially available urine strips (Mission ${ }^{\circledR}$, Accon laboratories, Inc.1025. Mesa Rim Road. San Diego, CA. USA) for protein, sugar and nitrite followed by microscopy of cells (Accon laboratories, Inc.1025. Mesa Rim Road. San Diego, CA. USA). Urine samples with leukocytes more than 10/ HPF were selected for further Studies. ${ }^{9}$ The selected urine samples were divided into two portions, one for culture and other for the PCR amplification.

Bacterial isolation and Identification: Classical bacteriological procedures were used for bacterial isolation from selected urine samples. Each sample was mixed well and inoculated on Cystine Lactose Electrolyte Deficient (CLED) agar plates (Oxoid, United Kingdom) using a $5 \mathrm{~mm}$ diameter calibrated wire loop followed by incubation aerobically at $37^{\circ} \mathrm{C}$ for $24 \mathrm{hrs}$. Plates were observed for bacterial growth and the isolated colonies were further triple cloned. Bacterial isolates were identified by analytical profile index (API), API 20E and API 20NE system (bioMerieux, France) according to the manufacturer's directions (Analytical Profile Index API). ${ }^{10}$ (http://www.biomerieux-usa.com/ clinical/api). Bacterial genomic DNA was extracted using, Thermo Scientific Genomic Purification Kit, Lithuania, following the manufacturer's instructions. 16S rDNA gene was amplified using universal primers, 27F-5' - AGA GTT TGA TCC TGG CTC AG -3' and RD1-5' - AAG GAG GTG ATC CAG CC $-3^{\prime}$ for the amplification of an internal fragment of $1500 \mathrm{bp}$. Applied Biosystem, USA thermocycler was used with Initial denaturation temperature, $95^{\circ} \mathrm{C}$ for two minutes, followed by 35 cycles of 30 seconds at $95^{\circ} \mathrm{C}, 30$ seconds at $55^{\circ} \mathrm{C}$ and two minutes at $72^{\circ} \mathrm{C}$. A final extension was carried at $72^{\circ} \mathrm{C}$ for 10 minutes. ${ }^{11}$. Sequencing of the PCR product of $16 \mathrm{~S}$ rDNA genes of the representative samples was carried out commercially through Macrogen, South Korea. Sequences were aligned using Basic Local Alignment Search Tool (BLAST). https:/ / blast.ncbi. nlm.nih.gov/Blast.cgi?PROGRAM=blastn\&PAGE_ TYPE=BlastSearch\&LINK_LOC=blasthome.

Antimicrobial Susceptibility: The standardized antibacterial sensitivity test was performed on Mueller-Hinton agar plates using disc diffusion Kirby Bauer technique with 0.5 McFarland turbidity standard methods and results were interpreted according to CLSI 2014 (CLSI. M100-S124.; 2014). ${ }^{12}$ blaNDM-1 gene detection: Plasmid DNA was extracted for selected phenotypically carbapenem resistant isolates using GeneJET Plasmid Miniprep Kit by Thermo Fisher Scientific Lithuania, according to the manufacturer's instructions. The blaNDM-1 gene was amplified by polymerase chain reaction (PCR) using primers; F-5'- GGG CAG TCG CTT CCA ACG GT-3' and R-5'- GTA GTG CTC AGT GTC GGC AT -3'. Conditions for PCR were set to; initial denaturation at $95^{\circ} \mathrm{C}$ for five minutes, followed 30 Cycles of $95^{\circ} \mathrm{C}$ for 40 seconds, $58^{\circ} \mathrm{C}$ for 30 seconds, $72^{\circ} \mathrm{C}$ for 30 seconds with Final extension $72^{\circ} \mathrm{C}$ for 5 minutes..$^{13}$ After amplification, 
Table-I: Patients and their categorical data.

\begin{tabular}{|c|c|c|c|c|c|c|c|c|c|c|}
\hline Total No. & OPD $n(\%)$ & Indoor $n(\%)$ & Male n (\%) & Female $n(\%)$ & \multicolumn{3}{|c|}{ Age Categories/years } & \multicolumn{3}{|c|}{ Pus Cells /HPF } \\
\hline \multirow{2}{*}{146} & \multirow{2}{*}{$84(57.53)$} & \multirow{2}{*}{$62(42.46)$} & \multirow{2}{*}{$64(43.83)$} & \multirow{2}{*}{$82(56.16)$} & $1-25$ & $26-50$ & $>50$ & $11-30$ & $30-50$ & $>50$ \\
\hline & & & & & 64 & 58 & 24 & 63 & 57 & 26 \\
\hline
\end{tabular}

DNA was loaded in 2\% agarose gel and connected to the electrophoresis device Wealtec ELITE-300 (S.\# E3W0578 UAS) by setting voltage 120 Amp, and $400 \mathrm{~mA}$ for 30 minutes. Electrophoresis gel was transferred to the gel documentation system Wealtec (USA) Dolphin-view S \# WDV 50710004 for reading Sequencing of the PCR product of blaNDM-1 genes of the representative samples was carried out commercially through Macrogen, South Korea. Sequences were aligned using Basic Local Alignment Search Tool. ${ }^{14}$

\section{RESULTS}

One hundred and seventeen $(n=146)$ urine samples out of 2032, taken from both male and female patients categorized age wise and on the basis of pus cells were identified based on cultural, morphological and biochemical characterization, and API system (Table-I). Five urine specimen having leukocytes more than 20 per HPF had no growth on CLED agar. Two of them were found to be due to Mycobacterium tuberculosis infection on further investigation. Three patients were taking injectable antibiotics, have shown no growth on culture and no resistant gene on molecular analysis. Out of 146 bacterial isolates, the bacteria isolated were, Escherichia coli, Klebsiella pneumoniae, Pseudomonas aeruginosa and Proteus mirabilis were identified respectively (Table-II).
Table-II: Number and percentage of isolated bacterial pathogens.

\begin{tabular}{lcc}
\hline Name of organisms & Number $(n)$ & Percentage \\
\hline Escherichia coli & 99 & 67.80 \\
Klebsiella pnuemoniae & 33 & 22.60 \\
Pseudomonas aeruginosa & 11 & 7.53 \\
Proteus mirabilis & 3 & 2.05 \\
\hline
\end{tabular}

Antimicrobial sensitivity against a range of antibiotics, including those used in daily clinical practice and many broad spectrum are shown in (Table-III). All isolates belonging to four different spp, of Escherichia coli, Klebsiella pneumoniae, Pseudomonas aeruginosa and Proteus mirabilis were found, showing increased resistance against many broad spectrum antimicrobials. It is noted that uropathogens are becoming resistant to routinely prescribed oral antibiotics except nitrofurantoin. cephalosporin and quinolone drugs also gaining resistance.

Four carbapenem resistant bacterial isolates of two different spp. namely Escherichia coli (Ec-31, Ec-387 \& Ec-867 and Klebsiella pneumoniae (Kp-651) were positive for blaNDM-1 gene showing bands on 475bp position (Fig.1), Escherichia coli and Klebsiella pneumoniae harboring blaNDM-1 were resistant to all antibacterials including imepenem, meropenem

Table-III: Resistance pattern of isolated bacteria from UTI cases.

\begin{tabular}{|c|c|c|c|c|c|c|c|c|}
\hline \multirow[b]{2}{*}{$\begin{array}{l}\text { Names of } \\
\text { Pathogens }\end{array}$} & \multicolumn{8}{|c|}{ Resistant markers (Disc diffusion method) } \\
\hline & $\begin{array}{c}F \\
n(\%)\end{array}$ & $\begin{array}{c}\text { PIP } \\
n(\%)\end{array}$ & $\begin{array}{c}N A \\
n(\%)\end{array}$ & $\begin{array}{l}\text { FOS } \\
n(\%)\end{array}$ & $\begin{array}{l}I P M \\
n(\%)\end{array}$ & $\begin{array}{c}A K \\
n(\%)\end{array}$ & $\begin{array}{c}C I P \\
n(\%)\end{array}$ & $\begin{array}{l}C A Z \\
n(\%)\end{array}$ \\
\hline $\begin{array}{l}\text { Escherichia coli } \\
(n=99)\end{array}$ & $7(7.07)$ & $80(80.80)$ & $90(90.90)$ & $8(8.08)$ & $3(3.03)$ & $9(9.09)$ & $74(74.74)$ & $57(57.57)$ \\
\hline $\begin{array}{l}\text { K.pneumoniae } \\
(n=33)\end{array}$ & $4(12.12)$ & $30(90.90)$ & $31(93.93)$ & $5(15.15)$ & $1(3.03)$ & $1(3.03)$ & $7(21.21)$ & $5(15.15)$ \\
\hline $\begin{array}{l}\text { P. aeruginosa } \\
(n=11)\end{array}$ & $\mathrm{Na}$ & $11(100)$ & $11(100)$ & $6(54.54)$ & 0 & $1(9.09)$ & $3(37.5)$ & $3(27.27)$ \\
\hline $\begin{array}{l}\text { Proteus mirabilis } \\
(\mathrm{n}=3)\end{array}$ & $\mathrm{Na}$ & $3(100)$ & $3(100)$ & $0(0)$ & $0(0)$ & $0(0)$ & $0(0)$ & $0(0)$ \\
\hline
\end{tabular}

Key: F: Nitrofurantoin. NA: Nalidaxic Acid. FOS: Fosfomycin. IPM: Imepenem. AK:Amikacin. CIP: Ciprofloxacin. OFX: Ofloxacin. CAZ: Ceftazedime. CTX: Cefatoxime. CRO: Ceftriaxone. Na: Not applicable. 


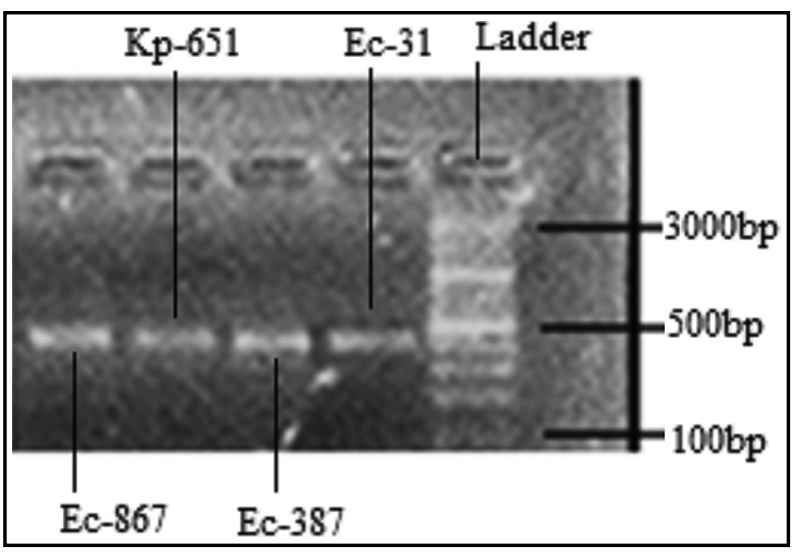

Fig.1: blaNDM-1 bands on 475bp position.

and ertapenem while susceptible to polymaxin-B, tygacycline and colistin. (Table-IV).

\section{DISSCUSSION}

The previous studies showed, urinary tract infection as the most common bacterial infections, prevalent in the hospitals and in the community. ${ }^{15}$ Escherichia coli were responsible for the majority of the infections. ${ }^{16}$

We have isolated bacterial pathogens of four different spp., Escherichia coli, Klebsiella pneumoniae, Pseudomonas aeruginosa, and Proteus mirabilis. In AKU Karachi urine samples were having E. coli (40\%), Pseudomonas sp. (16\%), Klebsiella sp. (11\%), Proteus sp. (13\%). ${ }^{17}$ In Gilgit Baltistan $47.7 \%$, were E. coli, 41\% Klebsiella pneumonia and 13.7\%, Enterococci $\mathrm{sp}$. In one of the recent studies from the USA, most common uropathogens remain Escherichia coli accounting about $70 \%$ of total cases followed by Proteus mirabilis, Klebsiella and Enterobacter. ${ }^{18}$ The E. coli and Klebsiella strains are becoming resistant to commonly used antibiotics. In the present study the most prevalent organism was E. coli $(67.80 \%)$. Furthermore, we found that UTI is more common in females $(56.16 \%)$, which is also in agreement with studies in the USA and in Pakistan.

Worldwide, there is gradual increase in antimicrobial resistance among uropathogens, in one of the study conducted in 2008 had found that $E$. coli was resistant against ampicillin cotrimoxazole, ciprofloxacin, gentamicin, nitrofurantoin and amikacin (92\%), (80\%), (62\%), (47\%), (20\%) and $(4 \%)$ respectively. ${ }^{19}$ Whereas, in our study resistance percentage against ciprofloxacin was $76 \%$ and Amikacin 9\%, which is alarming in the region. In another study E.coli isolates were found susceptible to carbapenems (100\%), amikacin (98.1\%), cephalosporins, (96.2\%) and piperacillin-
Table-IV: Susceptibility pattern of blaNDM-1 positive isolates.

\begin{tabular}{lcccccc}
\hline Isolate & IPM & MEM & ETP & CS & TGC & $P B$ \\
\hline Ec-31 & $\mathrm{R}$ & $\mathrm{R}$ & $\mathrm{R}$ & $\mathrm{S}$ & $\mathrm{S}$ & $\mathrm{S}$ \\
Ec-387 & $\mathrm{R}$ & $\mathrm{R}$ & $\mathrm{R}$ & $\mathrm{S}$ & $\mathrm{S}$ & $\mathrm{S}$ \\
Kp-651 & $\mathrm{R}$ & $\mathrm{R}$ & $\mathrm{R}$ & $\mathrm{S}$ & $\mathrm{S}$ & $\mathrm{S}$ \\
Ec-867 & $\mathrm{R}$ & $\mathrm{R}$ & $\mathrm{R}$ & $\mathrm{S}$ & $\mathrm{S}$ & $\mathrm{S}$ \\
\hline
\end{tabular}

Key:- Imipenem (IPM), Meropenem (MEM),

Ertapenem (ETP),

Colistin (CT), Tigecyclin (TGC), Polymyxin-B (PB).

tazobactam (88.5\%), whereas fluoroquinolones were found highly potent against E.coli, but rate of high resistance to ciprofloxacin has also been observed. ${ }^{20}$ The E.coli and Klebsiella strains are becoming resistant against commonly used antibiotics ${ }^{21}$, and drugs used for prophylactic use..$^{22}$ We found $3.03 \%$ and $9.09 \%$ resistance against imipenem and amikacin respectively in E. coli and Klebsiella strains which is an evidence of increasing resistance.

The rise in drug resistance is alarming, especially as new resistant gene NDM-1 has been discovered in E. coli, and Klebsiella. ${ }^{23}$ From urine samples seven carbapenem-resistant NDM-1-positive Klebsiella pneumoniae isolates were recovered, from patients in different wards at a referral and tertiary care centers in Nairobi. All isolates were positive for blaNDM-1 carbapenemase gene. ${ }^{24}$ Molecular detection of bacteria is becoming a common mode of diagnosis, which not only reduces the diagnostic time but also helps in detection of resistance genes. In UK the E. coli was causing infections having extended-spectrum beta-lactamase (ESBL) which was confirmed in Health Protection Agency (HPA) report. These were predominantly of the type CTX-M-15. Most strains were resistant to betalactams and other classes of antibiotics and, in some cases, only carbapenem and aminoglycosides were susceptible. ${ }^{25}$ In the present study, we have isolated four blaNDM-1 positive isolates of E. coli and Klebsiella. The presence of NDM-1 in diverse microbial species and increasing antimicrobial resistance in urinary tract infections imposes precise and early detection, particularly in view of the limited treatment options available and where irrational use of antimicrobial in the region is a common practice. Moreover, it is also proved that molecular diagnosis is more reliable and less time consuming as compared to the traditional culture and sensitivity which is more time consuming in favor of the patients suffering from UTI,s. 


\section{CONCLUSIONS}

In brief E.coli is observed the most common bacteria causing urinary tract infection in all ages and both sexes but female patients suffer more than the male patients due to poor hygiene. Molecular detection is more potent and less time consuming than a routine culture and sensitivity. To the best of our knowledge this is the first report on direct molecular detection of bacterial pathogens from urinary tract infected patients in the province of Balochistan. The presence of $b l a_{\mathrm{NDM}-1}$ in different bacterial species and their extensive drug resistance pattern poses a significant clinical health threat. Moreover, direct and early molecular detection of UTI will help the physicians in avoiding irrational prescribing of antibiotics.

Acknowledgement: The cooperation of Dr. Mohammad Masood Tariq, Director, Center for Advanced Studies in Vaccinology and Biotechnology, University of Balochistan, Quetta, is acknowledged for the molecular diagnostic facility.

Conflict of Interest: None.

\section{Grant Support \& Financial Disclosures: None.}

\section{REFERENCES}

1. Steensberg J, Bartels ED, Bay-Nielsen H, Fanoe E, Hede T. Epidemiology of urinary tract diseases in general practice. $\mathrm{Br}$ Med J. 1969;4(5680):390-394. doi: 10.1136/bmj.4.5680.390

2. Gupta K, Trautner B. Urinary tract infection. Ann Iintern Med. 2012;156(5):ITC3-ITC15. doi: 10.7326/0003-4819-156-5201203060-01003

3. Flores-Mireles AL, Walker JN, Caparon M, Hultgren SJ. Urinary tract infections: epidemiology, mechanisms of infection and treatment options. Nat. Rev Microbiol. 2015;13(5):269. doi: 10.1038/nrmicro3432

4. Freedman AL, Urologic Diseases in America Project. Urologic diseases in North America Project: trends in resource utilization for urinary tract infections in children. J Uurol. 2005;173(3):949954. doi: 10.1097/01.ju.0000152092.03931.9a

5. Gales AC, Jones RN, Gordon KA, Sader HS, Wilke WW, Beach ML, et al. SENTRY Study Group Latin America T. Activity and spectrum of 22 antimicrobial agents tested against urinary tract infection pathogens in hospitalized patients in Latin America: Report from the second year of the SENTRY antimicrobial surveillance program (1998). J Antimicrob Chemother. 2000;45(3):295-303. doi: 10.1093/jac/45.3.295

6. Rubin RH, Shapiro ED, Andriole VT, Davis RJ, Stamm WE. Evaluation of new anti-infective drugs for the treatment of urinary tract infection. Clin. Infect. Dis. 1992;15(Suppl_1):S216-S227. doi: 10.1093/clind/15.Supplement_1.S216

7. Janda JM, Abbott SL. 16S rRNA gene sequencing for bacterial identification in the diagnostic laboratory: pluses, perils, and pitfalls. J Clin Microbiol. 2007;45(9):2761-2764. doi: 10.1128/ JCM.01228-07

8. Mezger A, Gullberg E, Goransson J, Zorzet A, Herthnek D, Tano E, et al. A general method for rapid determination of antibiotic susceptibility and species in bacterial infections. J Clin. Microbiol. 2015;53(2):425-432. doi: 10.1128/ JCM.02434-14
9. Wilson ML, Gaido L. Laboratory diagnosis of urinary tract infections in adult patients. Clin Infect Dis. 2004;38(8):1150-1158.

10. Analytical Profile Index API. System S.A. Labalmeles Grottes 38390 montalieu vercieu.

11. Yan JJ, Wu JJ, Ko WC, Tsai SH, Chuang CL, Wu HM, et al. Plasmid-mediated 16S rRNA methylases conferring high-level aminoglycoside resistance in Escherichia coli and Klebsiella pneumoniae isolates from two Taiwanese hospitals. J Antimicrob Chemother. 2004;54(6):1007-1012. doi: $10.1093 / \mathrm{jac} / \mathrm{dkh} 455$

12. CLSI. Performance standards for antimicrobial susceptibility testing, Clinical and Laboratory Standard Institute. CLSI document, Wayne, PA. 2014;M100-S124.

13. Mushtaq S, Irfan S, Sarma JB, Doumith M, Pike R, Pitout J, et al. Phylogenetic diversity of Escherichia coli strains producing NDM-type carbapenemases. J Antimicrob Chemother. 2011;66(9):2002-2005. doi: 10.1093/jac/dkr226

14. Weisburg WG, Barns SM, Pelletier DA, Lane DJ. 16S ribosomal DNA amplification for phylogenetic study. J Bacteriol. 1991;173(2):697-703. doi: 10.1128/jb.173.2.697-703.1991

15. Manges AR, Johnson JR, Foxman B, O'bryan TT, Fullerton KE, Riley LW. Widespread distribution of urinary tract infections caused by a multidrug-resistant Escherichia coli clonal group. N Engl J Med. 2001;345(14):1007-1013. doi: 10.1056/NEJMoa011265

16. Katouli M. Population structure of gut Escherichia coli and its role in development of extra-intestinal infections. Iran J Microb. 2010;2(2):59.

17. Farooqui BJ, Alam M, Khurshid M. Urinary tract infection. J Pak Med Assoc. 1989;39:129-131.

18. Williams JD, Thomlinson JL, Cole JG, Cope E. Asymptomatic urinary tract infection in gynaecological outpatients. Br Med J. 1969;1(5635):29-31. doi: 10.1136/bmj.1.5635.29

19. Vazouras K, Velali K, Tassiou I, Anastasiou-Katsiardani A, Athanasopoulou K, Barbouni A, et al. Treatment and Antimicrobial Resistance in Children with Urinary Tract Infections. J Glob Antimicrob Resist. 2019;20:4-10. doi: 10.1016/j. jgar.2019.06.016

20. Bashir MF, Qazi JI, Ahmad N, Riaz S. Diversity of urinary tract pathogens and drug resistant isolates of Escherichia coli in different age and gender groups of Pakistanis. Trop J Pharm Res. 2008;7(3):1025-1031. doi: 10.4314/tjpr.v7i3.14687

21. Rubin RH, Shapiro ED, Andriole VT, Davis RJ, Stamm WE Evaluation of new anti-infective drugs for the treatment of urinary tract infection. Clin Infect Dis. 1992;15(Suppl 1):S216-S227. doi: 10.1093/clind/15.Supplement_1.S216

22. Lloyd JC, Hornik CP, Benjamin DK, Clark RH., Routh JC, Smith PB. Incidence of Breakthrough Urinary Tract Infection in Hospitalized Infants Receiving Antibiotic Prophylaxis. Clin. Pediatr. 2016;56(1):65-70. doi: 10.1177/0009922816638664(24)

23. Chishti AS, Maul EC, Nazario RJ, Bennett JS, Kiessling SG. A guideline for the inpatient care of children with pyelonephritis. Ann Saudi Med. 2010;30(5):341-349. doi: 10.4103/0256-4947.68549

24. Poirel L, Revathi G, Bernabeu S, Nordmann P. Detection of NDM-1-producing Klebsiella pneumoniae in Kenya. Antimicrob Agents Chemother. 2011;55(2):934-936. doi: 10.1128/ AAC.01247-10

25. Deshpande P, Rodrigues C, Shetty A, Kapadia F, Hedge A, Soman R. New Delhi Metallo-beta lactamase (NDM-1) in Enterobacteriaceae: Treatment options with carbapenems compromised. J Assoc Physicians India. 2010;58:147-149.

\section{Author's Contribution:}

GSP, MAA, FA: conceived, designed and editing of the manuscript.

MD: Data collection and manuscript writing.

All authors are collectively responsible for accuracy \& integrity of the work, especially the principle author (GSP). 